\title{
Voting with our feet
}

\section{Abi Berger (1)}

\section{Correspondence to DrAbi Berger; info.bmjsrh@ bmj.com}

Received 3 August 2019 Accepted 30 August 2019
Check for updates

(C) Author(s) (or their employer(s)) 2019. No commercial re-use. See rights and permissions. Published by BMJ.

To cite: Berger A. BMJ Sex Reprod Health 2019;45:302.
For better or worse, healthcare has become a commodity. In London where I work, there has been a huge shift of mostly younger patients registering with the kind of services which seem to offer instant gratification. These patients are moving in droves away from the stable 'register with a general practice surgery near to where you live' to the online and telephone services they can access on their phones. These are 'consumers' who don't want face-to-face or continuity of care. They just want to get sorted as quickly as possible and wherever they happen to be. They won't wait 3-4 weeks for a routine appointment. Whether we like it or not, these services are meeting a demand that has taken most of us by surprise.

There are doctors who appear to enjoy working for these services; general practitioners (GPs) who want to work from home on their computers or phones and who don't seek to foster relationships with patients. We are producing GPs who want to offer their services as a commodity. I may initially feel affronted by what these individuals are choosing to do with their medical training, but when I take a more neutral view of this changing world I can see it cuts both ways. These are consumer patients and doctors who fit well.

But it's not just young, technologically savvy people who are choosing to vote with their feet. Last week I met a 72-year-old man in my consulting room. We had spoken briefly on the phone because I happened to be the duty doctor that morning, so I was familiar with his current health issues. Apart from his large prolapsed cervical disc causing neurological symptoms down his right arm, I had also seen from his electronic record that he had registered with three different GP surgeries in the space of aweek. I was shocked. He lives in a hostel for recently street homeless people. He came in, sat down facing me and we introduced ourselves.

To be honest I was blunt with him - I asked him outright why he had changed GP practice three times in aweek. He told me his story. At the first health centre he'd waited over 2 hours to see a GP. I assumed he meant they had a 'walk in and wait' policy. He wasn't happy with that experience. He then registered a few streets away and saw a GP who didn't look at him the entire time he was in the room he thought she was more interested in her computer. He then went to an accident and emergency department located some miles away. His scans weren't available there, but they gave him some medication to help with nerve pain.

His next port of call was my practice, just minutes away from the previous two places he'd tried out. The best thing I'd done without knowing it was to offer him a specific time to come in, to not keep him waiting too long, and to sit squarely looking at him, taking not even a sideways glance at the computer. We had a bit of a laugh, and I ascertained that despite his recent journey around the National Health Service (NHS) he did have an urgent appointment to see a spinal surgeon at a local hospital, and he intended to keep it. His medication was working but wasn't great. I gave him a new prescription for the same tablets but a higher dose. On his way out he looked back and said "I'll come back to see you after I've met the surgeon. You can bring me a piece of rock back from your holiday".

Competing interests None declared.

Patient consent for publication Not required.

Provenance and peer review Commissioned; internally peer reviewed.

\section{ORCID iD}

Abi Berger http://orcid.org/0000-0003-05149245 